\title{
Research Square \\ Phenotypic Plasticity and Genetic Variation of Leaf Pigment Content in a Southern Beech
}

\author{
Veronica Andrea El Mujtar \\ IFAB (INTA-CONICET) \\ Mario Juan Pastorino \\ IFAB (INTA-CONICET) \\ Paula Marchelli \\ IFAB (INTA-CONICET)
}

Jorge Andres Arias Rios ( $\square$ arias.jorge@inta.gob.ar )

CONICET Patagonia Norte https://orcid.org/0000-0003-2101-5749

\section{Research}

Keywords: chlorophyll, carotenoids, anthocyanins, Nothofagus alpina.

Posted Date: September 21st, 2021

DOI: https://doi.org/10.21203/rs.3.rs-889256/v1

License: (c) (1) This work is licensed under a Creative Commons Attribution 4.0 International License.

Read Full License 
Arias-Rios J.A. *; El Mujtar V.A.; Pastorino M; Marchelli P.

3

4

5

6

7

Keywords: chlorophyll, carotenoids, anthocyanins, Nothofagus alpina.

\section{Abstract}

Physiological, morphological and phenological attributes are potentially adaptive traits that determine functional responses to certain environmental conditions. They are crucial for understanding adaptations to environmental variation along a species natural range. In particular, leaf pigment content can be a good proxy to the physiological and phenological tree state. Our goal was to evaluate the variation in pigment traits among Nothofagus alpina populations in a common garden trail during two years to infer local adaptation and/or phenotypic plasticity. We also aim to analyse the correlation between pigment traits and phenological traits and climatic data from the geographic location of the populations. To comprise the entire range of the species in Argentina, we analysed 400 individuals from eight natural populations coming from four lake watersheds. Pigment traits were estimated using a spectrophotometer and analysed with linear mixed model (LMM). Significant differences among fixed factors (populations - years and watershed - years) were found in chlorophyl a, b, total, carotenoids and anthocyanins concentrations. Higher concentrations were found for 2018, year with the highest number of rainy days and accumulated precipitation. Two populations (Boquete and Tren Tren) were always the most contrasting ones. At population level, the correlation between the means of pigment concentrations and phenological traits 
was significant in almost all cases. Conversely, the correlation between the means of population pigment concentrations and the main geographic, climatic and bioclimatic variables of the home range were not significant. The significance of the environmental factor (year) in the linear mixed models tested is evidence of phenotypic plasticity of pigment content, suggesting flexibility for acclimatization to moderate inter-annual changes in climatic conditions. The significance of population and watershed and the influence of the family factor on the variance of the pigment traits are evidence of the genetic control as well as the potential adaptive value of leaf pigment content in $N$. alpina, giving a base for adaptation to a long-lasting change in climate. High correlations between phenological and pigment traits indicate that, in $N$. alpina, the determination of only one pigment concentration could be used as a proxy of bud burst, senescence and growing degree days.

\section{INTRODUCTION}

Climate has long been identified as a key factor shaping the geographic distribution of plants (Major 1951). In present times, however, climate is changing rapidly (IPCC 2014) shifting species distribution (Lloyd et al. 2011; Fisichelli et al. 2014; Parmesan and Hanley 2015). Tree species are particularly affected by these changes, that occur faster than their long life-cycle, and could respond through migration, phenotypic plasticity and local adaptation (Parmesan and Hanley 2015). However, uncertainty remains about dispersal rates in pace with rapidly changing climate as trees may not be able to track favourable conditions through migration (Kremer et al. 2012). Therefore, phenotypic plasticity (i.e. the capacity of genotypes to adapt their phenotypes without genetic changes) could be a strategy to persist in situ under changes of local conditions (Aitken et al. 2008). Ultimately, species can adapt to the new environmental conditions by natural selection of the most adequate genotypes (i.e. change of the allele genetic frequencies within populations). Exploring patterns of phenotypic plasticity and intraspecific genetic variation at adaptive traits can help to understand how species respond to changes in their environments. 
Potentially adaptive traits are physiological, morphological and phenological attributes that determine functional responses to certain environmental conditions (Violle et al. 2007). Variation in leaf pigment content can be a good proxy to the physiological tree state (Sims and Gamon 2002), and in particular photoprotective pigments play a relevant role in short-term responses to abiotic stress (García-Plazaola and Becerril 2000; Ramírez-Valiente et al. 2015). Chlorophyll a (Chla) and b (Chlb) are the main photosynthetic pigments, and photosynthetic capacity of plants is influenced by the total amount of leaf chlorophyll content $(\mathrm{Chla}+b)$ and the allocated ratio (Chla / Chlb) ( $\mathrm{Li}$ et al. 2018a). Accessory pigments such as carotenoids participate in reaction centers and dissipate excess of energy avoiding damage to the photosynthetic system (Demmig-Adams et al. 1996; Taiz, L., \& Zeiger 2002). Similarly, anthocyanins possess an antioxidant property preventing the production of free radicals and protecting the plant against UV light (Feild et al. 2001). High leaf anthocyanin concentrations have been determined at low temperatures or under other stressing conditions (Chalker-Scott 1999). interactions, common garden trials are a good choice to study the genetic control of potential adaptive traits (de Villemereuil et al. 2018). On these trials, different genetic entities (typically families nested within populations) are evaluated under homogenous environmental conditions, and therefore the differences in potential adaptive traits are assumed to be mainly of genetic origin (Kawecki and Ebert 2004). To test phenotypic plasticity of potentially adaptive traits, the same genetic entities must be installed in different environments. If the ontogenetic state of the organism has low influence on the analysed traits, phenotypic plasticity could also be evaluated by measuring traits repeatedly in the same trial in climatically contrasting years. Information from common garden trials has revealed genetic variation among populations for 

conform the southernmost temperate forests of the world (Marchelli et al., 2021a) . Climate change predictions for the region indicate increase in average temperature, decrease in average precipitation (Barros et al. 2015) and increase in the frequency and severity of extreme weather events (Alexander et al. 2006). These predicted changes would affect both thermal and rainfall gradients that characterized the region, and therefore the species growing along them. Nothofagus is the predominant genus in these forests. Among the native species, Nothofagus alpina (Poepp \& Endl.) Oerst. (= N. nervosa (Phil.) Dim. et Mil.), locally known as raulí, is an ecological and economical important tree species. To the eastern side of the Andes, where climate change is altering in particular the deep rainfall gradient (Barros et al. 2015), the species has a narrow and fragmented distribution along different watersheds (Marchelli et al., 2021b). Its occurrence along environmental gradients of precipitation and temperature (i.e. altitude) suggest the existence of local adaptations. Genetic differentiation at neutral (Marchelli and Gallo 2006; Azpilicueta et al. 2013) and adaptive markers related with drought stress responses (Soliani et al. 2020) suggested the co-occurrence of demographic and selection forces. Moreover, genetic variation in shoot/root allometric traits, bud burst phenology and foliar senescence was reported (Duboscq-Carra 2018; Duboscq-Carra et al. 2020). However, studies on other adaptive traits are still needed. In particular, studies on traits between pigment traits and climatic data from the geographic location of the populations. of forest tree species responses to stressful environmental conditions.

Our goal here was to evaluate the variation in pigment traits among $N$. alpina populations from different watersheds in a common garden trial during two years to infer local adaptation and/or phenotypic plasticity. Specifically, we aim to analyse: (i) the variation in chlorophyll $a$, chlorophyll $b$, total chlorophyll, carotenoids and anthocyanins (a) among natural populations and families within them and, (b) between two different years, (ii) the correlation between pigment traits and phenological traits in one of the years, and iii) the correlation 


\subsection{Common garden trial and climatic information}

113 For this study we used a provenance and progeny trial of $N$. alpina installed in 2011 in the INTA Forest station at Las Golondrinas (41 $59^{\prime} 50^{\prime \prime} \mathrm{S}, 71^{\circ} 31^{\prime} 31^{\prime \prime} \mathrm{W}, 415 \mathrm{~m}$ asl) where we had previously studied phenological traits (Duboscq-Carra et al. 2020). The trial consisted in a randomized complete block design with lineal blocks in order to take into consideration the shading effect of a parallel forest windbreak. A total of 400 trees were used, corresponding to 65 open pollinated families (at least 25 individuals per block and four individuals per family) from 10 blocks. These individuals represent eight natural populations coming from four lake watersheds that comprise the entire range of the species in Argentina (Table 1, Fig. 1). This region is characterized by dry summers (Donoso 2004) and N. alpina grows along a west-east mean annual precipitation gradient from $3000 \mathrm{~mm}$ to $1200 \mathrm{~mm}$ (Sabatier et al. 2011). Concerning thermal conditions, populations of $N$. alpina develop in places with high thermal amplitude, where warmest month mean temperatures are between $9-14^{\circ} \mathrm{C}$ and in the other species (Sabatier et al. 2011).

Daily minimum, maximum and mean air temperature, daily total precipitation for both years, and for the periods 1968-1977 (ten years) and 2012-2017 (six years), were obtained from the station 87800 of the Servicio Meteorológico Nacional $\left(41^{\circ} 57^{\prime} 0^{\prime \prime} \mathrm{S}, 71^{\circ} 32^{\prime} 0^{\prime \prime} \mathrm{W}, 337\right.$ $\mathrm{m}$ asl), located $5 \mathrm{~km}$ away from the common garden trial. These values were used to calculate monthly values of each variable (i.e. mean of daily values) for both years and mean monthly values for both periods (1968-1977 and 2012-2017). These periods were selected because they had almost complete data over each year (i.e. less than six missing values over the year). Climate data and bioclimatic variables from each geographic location of the $N$. alpina populations were also obtained, at 30 seconds spatial resolution $\left(\sim 1 \mathrm{~km}^{2}\right)$, from global databases. Historical monthly climate data for mean temperature, solar radiation, wind speed, water vapour pressure, and total precipitation for the period 1970-2000 were obtained from 
139 WorldClim v2.1 database (Fick and Hijmans 2017). Historical bioclimatic variables for the

140 period 1981-2010 were obtained from Chelsa v2.1 database (Karger et al. 2017).

Precipitation and temperature data were used to calculate the monthly De Martonne

142 aridity index (1926) following the equation:

143

144 Aridity Index $=12 *$ monthly amount precipitation / (mean monthly air temperature +10$)$

146 Table 1. Geographic location and climatic information of the eight analysed populations of

147 Nothofagus alpina with their corresponding watershed, number of families and individuals.

\begin{tabular}{|c|c|c|c|c|c|c|c|c|}
\hline Lake watershed & Population & Location & $\begin{array}{l}\text { Altitude } \\
\text { (m asl) }\end{array}$ & $\begin{array}{c}\text { MAP } \\
{[\mathrm{mm} \cdot \mathrm{yr}-1]^{\mathrm{a}}}\end{array}$ & $\begin{array}{l}\text { Jan. T } \\
\left({ }^{\circ} \mathrm{C}\right)^{\mathrm{a}}\end{array}$ & $\begin{array}{l}\text { July } \mathrm{T} \\
\left({ }^{\circ} \mathrm{C}\right)^{\mathrm{a}}\end{array}$ & $\mathrm{N}^{\circ}$ fam & $\mathrm{N}^{\circ}$ ind \\
\hline 1 -Tromen & Tromen bajo (TRB) & $\begin{array}{l}39^{\circ} 34^{\prime} 10^{\prime \prime} \mathrm{S} \\
71^{\circ} 26^{\prime} 28^{\prime \prime} \mathrm{W}\end{array}$ & 1064 & 1492 & 12.99 & 0.95 & 8 & 44 \\
\hline 1 -Tromen & Tromen alto (TRA) & $\begin{array}{l}39^{\circ} 36^{\prime} 18^{\prime \prime} \mathrm{S} \\
71^{\circ} 20^{\prime} 57^{\prime \prime} \mathrm{W}\end{array}$ & 1110 & 1270 & 13.5 & 1.01 & 13 & 69 \\
\hline $\begin{array}{l}2 \text {-Curruhué - } \\
\text { Huechulafquen }\end{array}$ & Paimún (P) & $\begin{array}{l}39^{\circ} 42^{\prime} 17^{\prime \prime} \mathrm{S} \\
71^{\circ} 33^{\prime} 52^{\prime \prime} \mathrm{W}\end{array}$ & 930 & 1800 & 12.1 & 0.93 & 6 & 39 \\
\hline $\begin{array}{l}2 \text { - Curruhué - } \\
\text { Huechulafquen }\end{array}$ & Curruhué (C) & $\begin{array}{l}39^{\circ} 50^{\prime} 04^{\prime \prime} \mathrm{S} \\
71^{\circ} 30^{\prime} 00^{\prime \prime} \mathrm{W}\end{array}$ & 1030 & 1400 & 13.2 & 0.89 & 9 & 54 \\
\hline 3- Lolog & Boquete (B) & $\begin{array}{l}40^{\circ} 01^{\prime} 51^{\prime \prime} \mathrm{S} \\
71^{\circ} 34^{\prime} 38^{\prime \prime} \mathrm{W}\end{array}$ & 910 & 1600 & 13.1 & 1.37 & 5 & 34 \\
\hline 3-Lolog & Puerto Arturo (PA) & $\begin{array}{l}40^{\circ} 01^{\prime} 02^{\prime \prime} \mathrm{S} \\
71^{\circ} 22^{\prime} 19^{\prime \prime} \mathrm{W}\end{array}$ & 910 & 1200 & 14.6 & 1.93 & 13 & 70 \\
\hline 4-Lácar & Queñi (QE) & $\begin{array}{l}40^{\circ} 09^{\prime} 54^{\prime \prime} \mathrm{S} \\
71^{\circ} 45^{\prime} 20^{\prime \prime} \mathrm{W}\end{array}$ & 920 & 2400 & 9.7 & 0.00 & 8 & 53 \\
\hline 4-Lácar & Tren Tren (TT) & $\begin{array}{l}40^{\circ} 11^{\prime} 53^{\prime \prime} \mathrm{S} \\
71^{\circ} 25^{\prime} 53^{\prime \prime} \mathrm{W}\end{array}$ & 1040 & 1400 & 13.8 & 1.61 & 7 & 37 \\
\hline
\end{tabular}

a Climatic data obtained from Bianchi and Cravero, 2010. MAP: mean annual precipitation, Jan. T:

149 mean January and July T: mean July temperatures. double column fitting table 


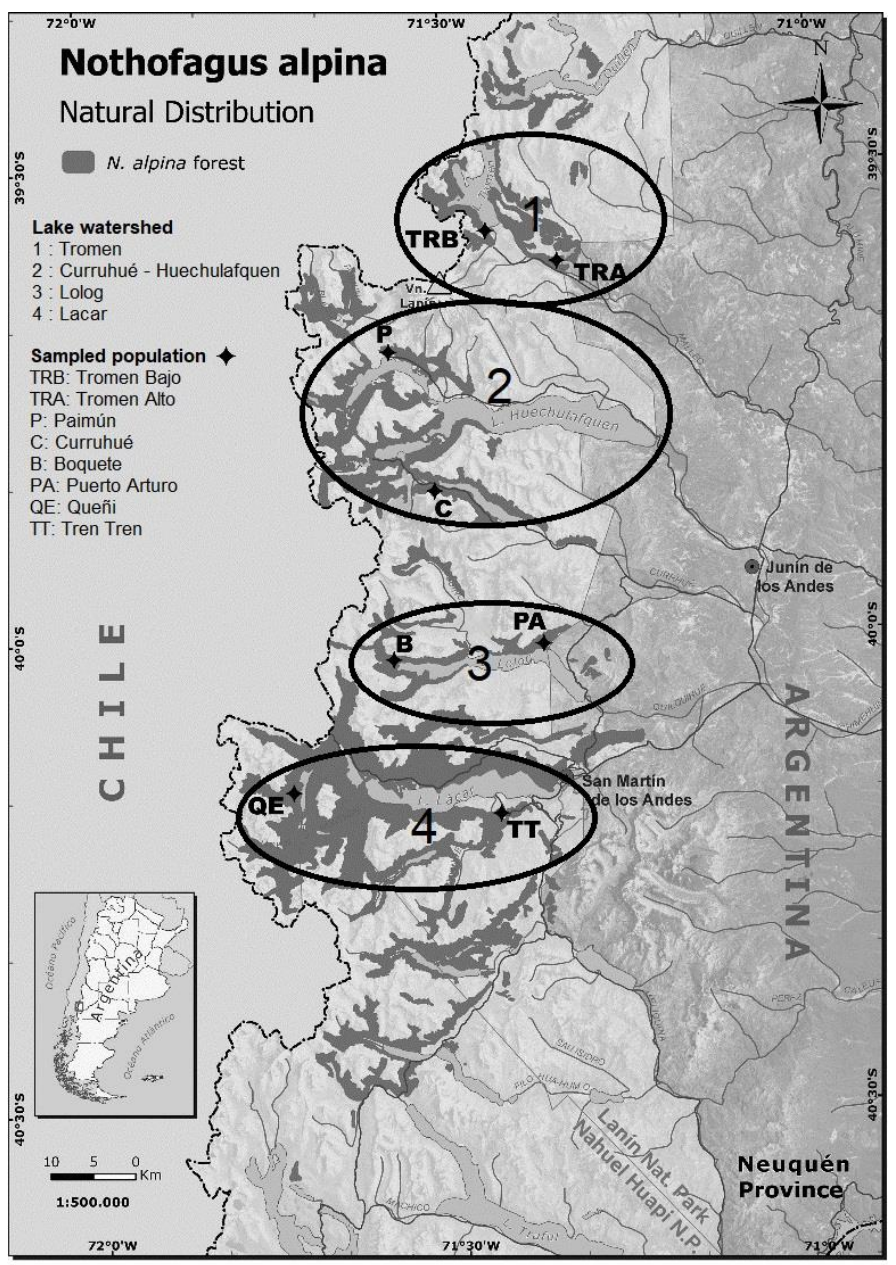

Fig. 1. Nothofagus alpina natural distribution in Argentina with the location of the studied populations and lake watersheds (modified from Duboscq-Carra et al., 2020). Simple column fitting image.

\subsection{Pigment quantification}

Fully expanded leaves (phase 5 according to Duboscq-Carra et al., 2020) were sampled in late spring (beginning of December) in 2018 and 2019. For each tree, we collected three not shaded leaves from different branches in different orientations. To avoid differences in environmental conditions (e.g. light intensity between days and within the canopy) that could bias phenotypic evaluation, each year we sampled the whole trial in a single day. Once collected, leaves were immersed in liquid nitrogen, transported to the laboratory and stored at $-80^{\circ} \mathrm{C}$ until pigment quantification. 
Chlorophylls and carotenoids were extracted using a solution of acetone: $\mathrm{H}_{2} \mathrm{O}(4: 1 \mathrm{v} / \mathrm{v})$ while anthocyanins were extracted using a solution of $3 \mathrm{M} \mathrm{HCl}: \mathrm{H}_{2} \mathrm{O}: \mathrm{MeOH}(1: 3: 16 \mathrm{v} / \mathrm{v} / \mathrm{v})$. For each tree, three foliar discs, $1 \mathrm{~cm}^{2}$ total area, were cut and submerged in each solution during 24 hours in dark at $4{ }^{\circ} \mathrm{C}$. After this period, centrifugation ( $1 \mathrm{~min}$ at $1000 \mathrm{rpm}, 4^{\circ} \mathrm{C}$ ) was used to separate solid residues. Pigment concentrations were estimated using a Pharmacia Biotech Ultrospec 1000 spectrophotometer. For the acetone extracts, absorbance was measured at 470, 647 and $663 \mathrm{~nm}$ (A470, A647 and A663 respectively) to estimate the concentration of chlorophyll a (Chla), chlorophyll b (Chlb), total chlorophyll (Chla+b) and total carotenoids (Car) according to the equations given by Lichtenthaler, 1987:

Chlorophyll a $=12,25 * A 663-2.79 * A 647$

Chlorophyll $b=21.50 * A 647-5.10 * A 663$

Chlorophyll total $=7.15 * A 663+18.71 * A 647$

Carotenoids $=\frac{(1000 * \text { A470 }-1,82 \times \text { Chlorophyll a }-85,02 \times \text { Chlorophyll } \mathrm{b})}{198}$

Chla / Chlb and Chla+b / Car ratios were also calculated.

For the methanolic extracts, absorbance was measured at 530 and $653 \mathrm{~nm}$ (A530 and A653 respectively) to estimate the concentration of anthocyanins (Ant) as Gould et al. (2000):

Anthocyanins $=A 530-0.24 * A 653$

\section{Statistical analysis}

Evaluation of environmental variation between both years at the common garden trial was based on temperature, precipitation and aridity index data. First, we tested the difference between years for monthly mean, minimum and maximum air temperature $\left(T_{\operatorname{mean}}, T_{\min }, T_{\max }\right.$ 
days (rd) we used the Mann-Whitney test. Normality of the data distribution was assessed using a histogram and a Shapiro test for each variable. Homoscedasticity was checked with a Bartlett test. Second, we compared the distribution pattern of monthly mean air temperature, total precipitation and aridity index for both years and mean historical values for the period 1970-2000 (WorldClim) and 1981-2010 (Chelsa).

To evaluate the relative contribution of our sampling effects (i.e. population, year, and random variance within blocks and families) to variation in the pigment traits we used a linear mixed effects model (LMM). We considered the following LMM:

$$
y_{i j k l}=\mu+\gamma_{i}+\rho_{j}+\gamma_{i} * \rho_{j}+\varphi_{k\left(\rho_{j}\right)}+\beta_{l}+\varepsilon_{i j k l}
$$

where: $y_{i j k l}$ is the pigment trait in the individual of the $k^{\text {th }}$ family of the $f^{\text {th }}$ population in the $f^{\text {th }}$ block measured in the $i^{\text {th }}$ year; $\mu$ is the general mean of the whole trial for the pigment trait; $\gamma_{i}$ is the fixed effect of the $i^{\text {th }}$ year; $\rho_{j}$ is the fixed effect of the $f^{\text {th }}$ population; $\varphi_{k\left(\rho_{j}\right)}$ is the random effect of the $k^{\text {th }}$ family nested into the $j^{\text {th }}$ population; $\beta_{l}$ is the random effect of the $I^{\text {th }}$ block; $\varepsilon_{i j k l}$ is the residual error $\sim \operatorname{NID}\left(0, \sigma^{2}\right)$.

We also evaluated the relative contribution of the watershed and year effect to variation in the pigment traits, considering the following LMM:

$$
y_{i m j l}=\mu+\gamma_{i}+\rho_{m}+\gamma_{i} * \rho_{m}+\varphi_{j\left(\rho_{m}\right)}+\beta_{l}+\varepsilon_{i m j l}
$$

where: $y_{\text {imjl }}$ is the pigment trait in the individual of the $j^{\text {th }}$ population of the $m^{\text {th }}$ watershed in the $f^{\text {th }}$ block measured in the $i^{\text {th }}$ year; $\mu$ is the general mean of the whole trial for the pigment trait; $\gamma_{i}$ is the fixed effect of the $t^{\text {th }}$ year; $\rho_{m}$ is the fixed effect of the $m^{\text {th }}$ watershed; $\varphi_{j\left(\rho_{m}\right)}$ is the random effect of the $f^{\text {th }}$ population nested into the $m^{\text {th }}$ watershed; $\beta_{l}$ is the random effect of the $t^{\text {th }}$ block; $\varepsilon_{i j k l}$ is the residual error $\sim N I D\left(0, \sigma^{2}\right)$.

For both LMMs, we used the "Ime4" package (Bates et al., 2016) in R 3.3.0 software (RStudio Team 2020). For each pigment trait model, we used a "residuals versus fitted plot" to detect non-linearity, unequal error variances, and outliers. A likelihood ratio test (LRT) was used to analyse the significance of random effects, considering the complete model and a model without each factor. 
Since the measurements of pigment content were made in consecutive years, the same development stage (juvenile trees) was evaluated. So, the traits are not expected to be influenced by the age of the trees, and the possible ontogenetic effect on the inter-annual variation was consequently dismissed.

Pearson correlation tests were performed between pigment traits and the main geographic and environmental variables of each natural population (Table 1). In addition, we tested the association between the estimated pigment concentrations and the phenological traits that showed significant differences among populations in Duboscq-Carra et al. (2020). Those traits were: day of the year to bud burst (DOY BB), growing degree days (GDD Tb 5 ${ }^{\circ} \mathrm{C}$ ), day of the year when $10 \%$ of the crown had autumnal leaves (DOY 10), and growing season length (GSL 10). This information was only available for the year 2018.

A principal component analysis (PCA) was performed considering mean values of Chla, Chlb, Chla+b, Car, Ant, Chla / Chlb and Chla+b / Car of each population as active quantitative variables. Mean climatic (5) and bioclimatic variables (35) from WorldClim and Chelsa, and the previously mentioned phenological variables (4) were used as supplementary quantitative variables in order to visualize potential relationships with pigment traits.

Watershed and longitudinal location (i.e. west or east location) were used as qualitative variables for data visualization. We used the R package Factoshiny v2.2 for this analysis. The Wilks test was used to evaluate which qualitative variable better explain the distance between populations. Factoshiny was also used to test the correlation between pigment content and climatic and bioclimatic variables.

\section{RESULTS}

\subsection{Climatic conditions of the evaluated years}

Globally, a tendency of higher number of rainy days and accumulated precipitation for 2018 than for 2019 was observed (Table 2). This tendency was even stronger for spring months, with threefold total precipitation and almost double the 
number of rainy days recorded in the spring of 2018 compared to the spring of 2019 (Table 2). However, no significant differences were found, by t-test or Mann-Whitney test, between years for the analysed variables (i.e. monthly rainy days, total precipitation, mean, minimum and maximum air temperatures, and aridity index, Table 2).

Table 2. Environmental conditions for the common garden trial located in Las Golondrinas for the evaluated years, including rainy days (rd), total precipitation (precip.), and mean values of monthly total precipitation (precip.), total rainy days ( $\mathrm{rd}$ ), mean, minimum and maximum air temperature ( $T_{\text {mean }}, T_{\min }, T_{\max }$ respectively) and aridity index (Al).

\begin{tabular}{ccccccccccc}
\hline Year & $\begin{array}{c}\text { Annual rd } \\
(\text { days })^{\mathrm{a}}\end{array}$ & $\begin{array}{c}\text { Spring } \\
\text { rd } \\
(\text { days })^{\mathrm{b}}\end{array}$ & $\begin{array}{c}\text { Annual } \\
\text { precip. } \\
(\mathrm{mm})^{\mathrm{a}}\end{array}$ & $\begin{array}{c}\text { Spring } \\
\text { precip. } \\
(\mathrm{mm})^{\mathrm{b}}\end{array}$ & $\begin{array}{c}\text { Mean } \\
\text { precip. } \\
(\mathrm{mm})^{\mathrm{c}}\end{array}$ & $\begin{array}{c}\text { Mean rd } \\
(\text { days })^{\mathrm{c}}\end{array}$ & $\begin{array}{c}\text { Mean } \\
\mathrm{T}_{\text {mean }}\left({ }^{\circ} \mathrm{C}\right)^{\mathrm{c}}\end{array}$ & $\begin{array}{c}\text { Mean } \mathrm{T}_{\min .} \\
\left({ }^{\circ} \mathrm{C}\right)^{\mathrm{c}}\end{array}$ & $\begin{array}{c}\text { Mean } \\
\mathrm{T}_{\text {max. }}\left({ }^{\circ} \mathrm{C}\right)^{\mathrm{c}}\end{array}$ & $\begin{array}{c}\text { Mean } \\
\mathrm{Al}^{\mathrm{c}}\end{array}$ \\
\hline 2018 & 122 & 36 & 987.8 & 332.5 & 83.0 & 10.1 & 10.94 & 3.58 & 17.08 & 56 \\
2019 & 105 & 22 & 813.6 & 112.5 & 67.7 & 8.75 & 11.16 & 3.39 & 17.64 & 48 \\
\hline
\end{tabular}

a January to December. ${ }^{b}$ September to November. ${ }^{c}$ Mean: correspond to monthly mean value of the reported variable. and aridity index were not equally distributed for both years (Fig. 2). Total precipitation for 2018 was globally higher than the historical reference, except during late autumn and early winter; while total precipitation for 2019 was globally lower than the historical reference (Fig. 2). Mean temperatures were higher than those of the historical periods for almost all months, and for 2019 it was globally higher than for 2018. Changes on total precipitation showed a higher impact on aridity index (Fig. 2). The year 2018 was less arid than the year 2019 according to the aridity index, showing a lower number of months classified as extremely arid (Fig. 2). Furthermore, during growing seasons, as a consequence of the difference in accumulated precipitation, 2018 presented better conditions for tree growth, showing higher values of aridity index than 2019. 
Total precipitation

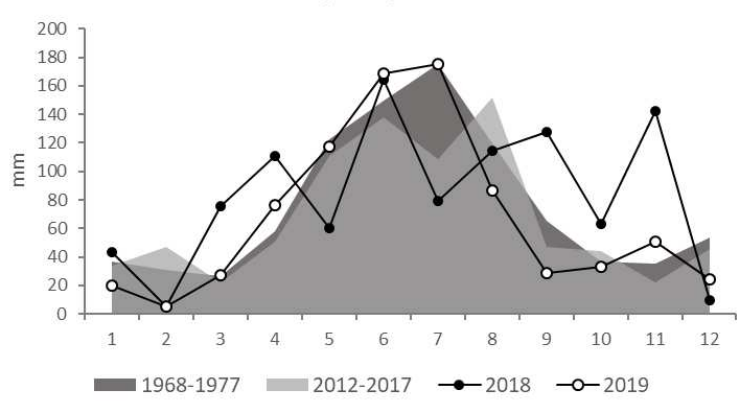

Mean temperature

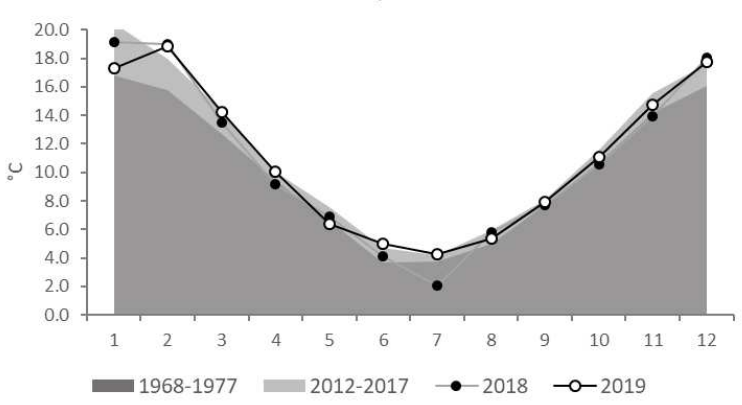

Aridity index

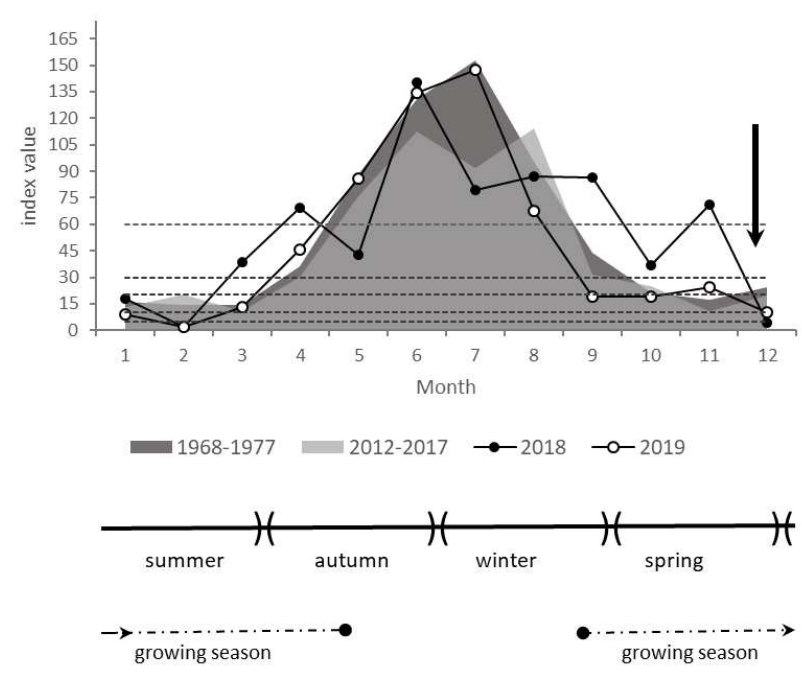

Fig. 2. Monthly mean temperature, total precipitation and aridity index of the common garden trial located in Las Golondrinas, for 2018, 2019 compared to mean values from the periods 1968-1977 and 2012-2017.Dashed lines in the y axis represents levels in climatic classification according to aridity index: 0-5: extremely arid; 5-10: arid; 10-20: semiarid; 20-30: subhumid; 30-60: humid; > 60 perhumid. Arrow indicates collecting date. Double column fitting image

\subsection{Leaf pigment variation}

Fixed factors were significant for both LMMs, while interaction between both fixed factors (i.e. population and year, or watershed and year) was not detected for any pigment trait (Table 3). Both for populations and for watersheds, the concentration of Chla, Chlb, Chla+b, Car and Ant all presented significant differences between years $(p<0.05)$, with higher concentrations in 2018 than in 2019 (Fig. 3 and Fig. 4). The difference was stronger for anthocyanin 
concentration. For example, among populations mean value of Ant concentration was 1.8 times higher in 2018 than in 2019 , while the other pigments showed a slightly higher concentration in 2018 than in 2019 ( 1.1 times).

Table 3. Significance of the fixed factor (population and year or watershed and year) and its interaction in LMMs for Chla, Chlb Chla+b, Chla/Chlb, Car, Chla+b/Car and Ant.

\begin{tabular}{cccccccc}
\hline $\begin{array}{c}\text { Fixed } \\
\text { Factor }\end{array}$ & Chla & Chlb & Chla+b & Chla / Chlb & Car & Chla+b/Car & Ant \\
\hline $\mathrm{P}$ & $2.6 \mathrm{e}-04$ & $7.4 \mathrm{e}-04$ & $3.6 \mathrm{e}-04$ & 0.1571 & 0.0343 & 0.8720 & $3.3 \mathrm{e}-04$ \\
$\mathrm{Y}$ & $6.6 \mathrm{e}-13$ & $1.9 \mathrm{e}-10$ & $1.2 \mathrm{e}-12$ & 0.5579 & $5.1 \mathrm{e}-05$ & 0.0373 & $<2.2 \mathrm{e}-16$ \\
$\mathrm{P} * \mathrm{Y}$ & 0.8634 & 0.8883 & 0.8835 & 0.8331 & 0.7341 & 0.6821 & 0.1630 \\
$\mathrm{~W}$ & $1.5 \mathrm{e}-09$ & $1.2 \mathrm{e}-08$ & $1.0 \mathrm{e}-09$ & 0.1257 & $1.4 \mathrm{e}-06$ & 0.5760 & 0.0436 \\
$\mathrm{Y}$ & $3.6 \mathrm{e}-12$ & $8.6 \mathrm{e}-10$ & $8.1 \mathrm{e}-12$ & 0.5570 & $1.2 \mathrm{e}-04$ & 0.0498 & $<2.2 \mathrm{e}-16$ \\
$\mathrm{~W} * \mathrm{Y}$ & 0.5308 & 0.5077 & 0.5542 & 0.5599 & 0.8024 & 0.3356 & 0.4086
\end{tabular}

a P:population, Y:year, W: watershed. *: interaction between fixed factors. Tren Tren were globally identified as the most contrasting populations showing the highest and the lowest concentration respectively. In particular, for Chla+b and Chla, Boquete and Puerto Arturo showed the highest concentrations, while Tren Tren and Queñi the lowest $(p<$ 0.05). Regarding Chlb, differences were significant $(p<0.05)$ between Boquete and Tren Tren, while the other populations were in the middle of these extremes. The family and block factors had a significant effect ( $\left.p_{L R T}<0.001\right)$, although they only explained around $6 \%$ and 10 $\%$ respectively in each variable. Carotenoids showed the same pattern as Chlb with Boquete showing the highest concentrations while Tren Tren the lowest. The random factors had significant effects ( $p_{\mathrm{LRT}}<0.001$ ), with family and block explaining $9 \%$ and $11 \%$ of the variability respectively. Finally, for anthocyanins, Boquete and Paimun had the highest concentrations while Tren Tren and Tromen Alto the lowest. Both random factors (family and block) had significant effect ( $p_{L R T}<0.001$ ) although they only explained around $4 \%$ of the total variance. 

concentrations. Lolog and Lácar were globally identified as the most contrasting watersheds showing the highest and lowest concentration respectively; while the other watersheds were in the middle of these extremes. The block factor had a significant effect $\left(\mathrm{p}_{L R T}<0.001\right)$, although it only explained around 5\% in Chla and Ant and around $10 \%$ in Chla $+b$, Chlb and Car of the total variance. The population nested into watershed factor did not have a significant effect in the model.

For both populations and watersheds, anthocyanins showed the highest level of intraspecific variation. For example, for populations, pigment content was $35 \%, 20 \%, 17.5 \%, 17 \%$, and $16 \%$ higher for Boquete than for Tren Tren, for Ant, Chlb, Car, Chla and Chla+b respectively. Considering watersheds, pigment content was $17 \%, 14 \%, 13 \%, 13 \%$ and $12 \%$ higher for Lolog than for Lacar, for Ant, Chlb, Car, Chla+b and Chla respectively. On the contrary, Chla / Chlb ratio and Chla+b / Car did not present significant 315 differences among populations, watersheds or years, with the exception of Chla $+b$ / Car for 316 which the difference between 2018 and 2019 was significant (Table 3). 

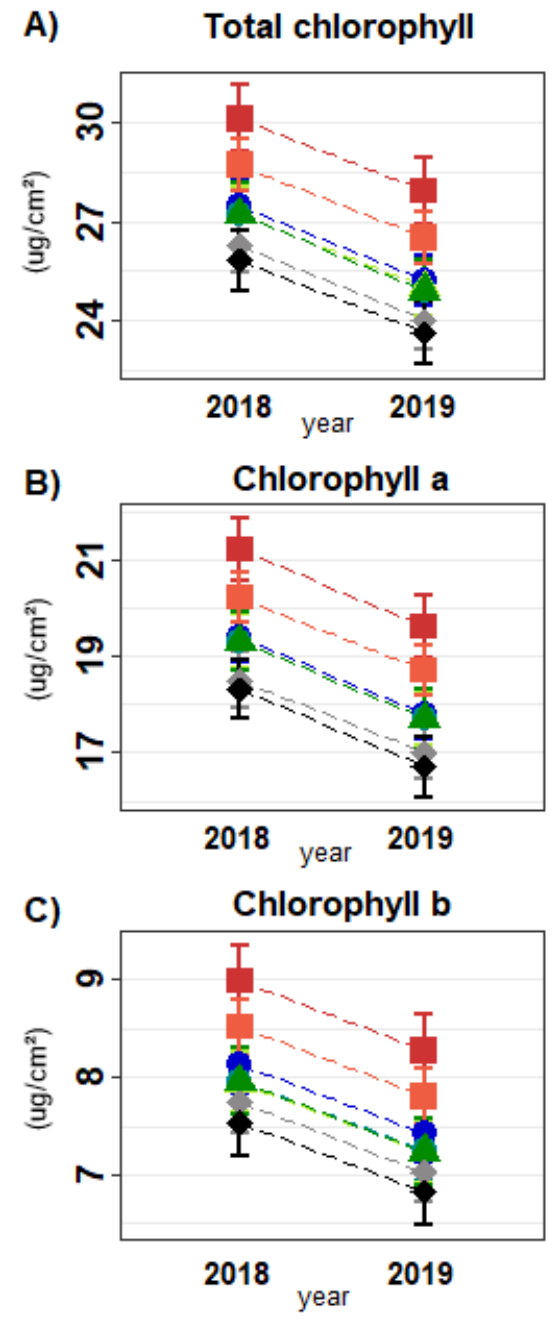
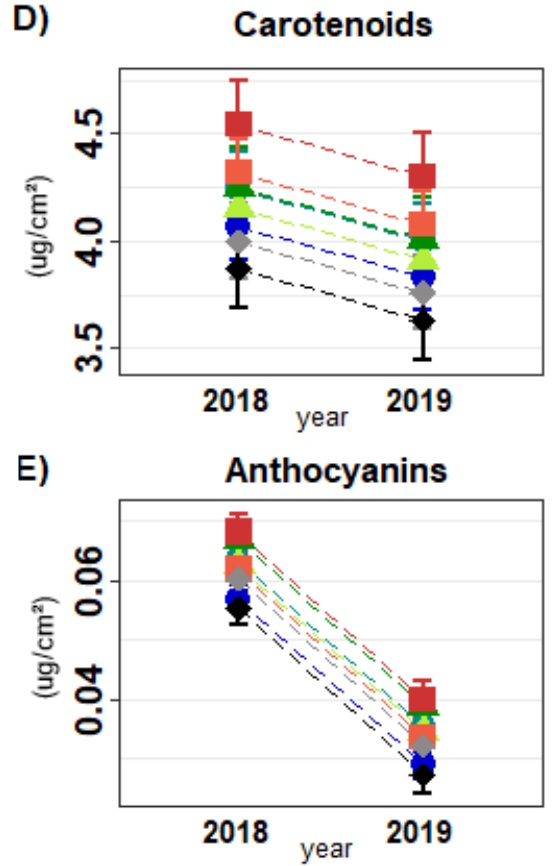

318 Fig. 3. Year by Population interactions for leaf pigment content in Nothofagus alpina.

319 Represented values are the mean effects on the LMM, with standard errors represented by 320 whiskers. Icon shape indicates watersheds: circles for Tromen, triangles for Curruhue321 Huechulafquen, squares for Lolog, diamond for Lácar. double column fitting image. 

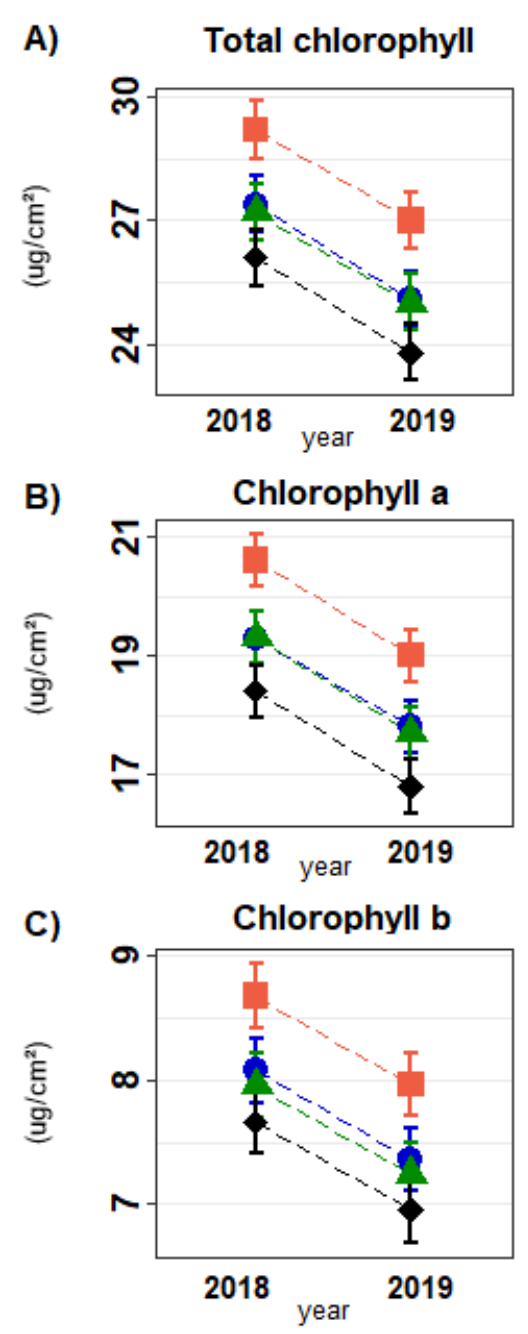
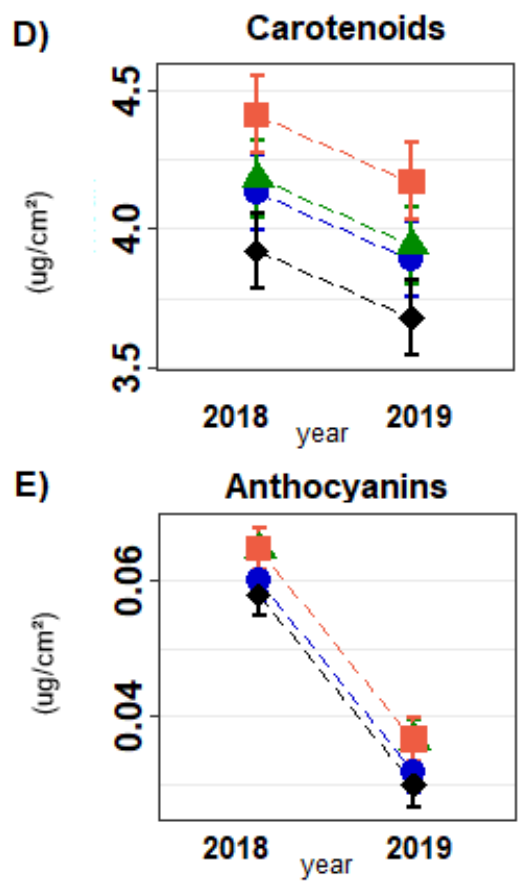

323 Fig. 4. Year by Watershed interactions for leaf pigment content in Nothofagus alpina.

324 Represented values are the mean effects on the LMM, with standard errors represented by whiskers. double column fitting image.

3.3 Correlation and principal component analyses

328 At population level, the correlation between the means of pigment concentrations and

329 phenological traits was significant in almost all cases, being high and negative for day of the 330 year to bud burst (DOY BB) and growing degree days (basal temperature $=5^{\circ} \mathrm{C}$; GDD $\mathrm{Tb} 5^{\circ}$ 331 C), and high and positive for beginning of senescence (DOY10) and growing season length 332 (GSL10) (Fig. 5). Conversely, the correlation between the means of population pigment 
concentrations and the main geographic and environmental variables of the home range (Table 1) were not significant. Moreover, significant correlations were not detected between pigment content and climatic and bioclimatic variables.

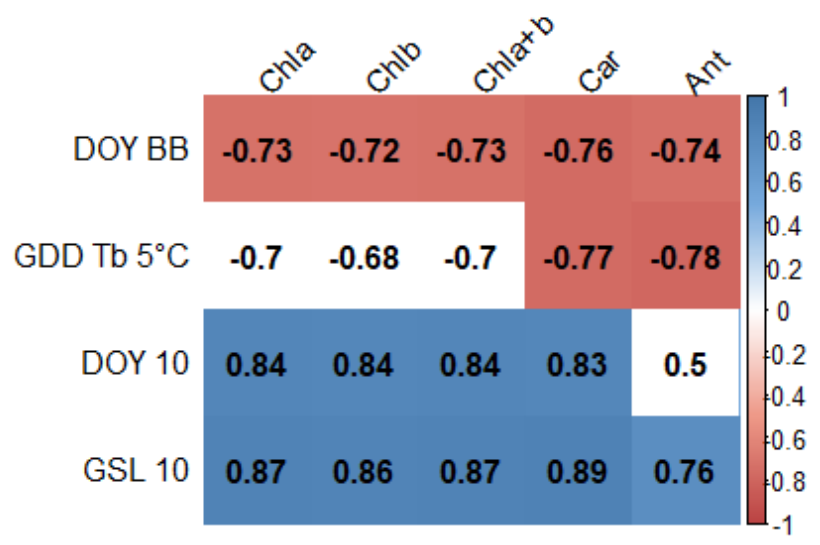

Fig. 5. Pearson correlation of pigments concentrations and phenological traits for Nothofagus alpina populations in 2018. Square colours identify significant correlations: red for negative, blue for positive. White squares mean no significant correlation ( $p$ value $>0.05$ ). simple

\section{column fitting image}

The first two dimensions of PCA analysis express $93.55 \%$ of the total variation (Fig. 6). This value was greater than the reference value (i.e. the 0.95 -quantile of the inertia percentages distribution obtained by simulating 1350 data tables of equivalent size on the basis of a normal distribution) that equals $74.1 \%$. The Wilks test $p$-value indicated that separation of the populations was better explained by watershed $(\mathrm{p}=0.070)$ than by longitudinal location $(\mathrm{p}=0.403)$.

The first dimension separate Boquete and Puerto Arturo (to the right of the graph, characterized by a strongly positive coordinate on the axis) and Tren Tren and Queñi (to the left of the graph, characterized by a strongly negative coordinate on the axis) populations (Fig. 6a). Boquete and Puerto Arturo had high values of Chla, Chla $+b$, Chlb, and Car and low values of Chla / Chlb; while Tren Tren and Queñi had an opposite trend of pigment traits. High 
correlation with this dimension was detected for Chla+b, Chla, Chlb, Car and Chla / Chlb (correlation $=0.99,0.99,0.98,0.87$ and -0.71 respectively) and GSL10, DOY10 and DOYBB (correlation $=0.87,084$ and -0.72 respectively) (Fig. 6b). Regarding watersheds, Lolog and Lácar showed a high positive and negative correlation with this dimension $\left(\cos ^{2}=0.99\right.$ and 0.98 respectively).

The second dimension separate Tromen Alto (to the bottom of the graph, characterized by a strongly negative coordinate on the axis) and Paimún (to the top of the graph, characterized by a strongly positive coordinate on the axis) populations (Fig. 6a). Tromen Alto had a low value of Chla / Chlb and a high value of Chla+b / Car; while Paimún had an opposite trend. Chla+b / Car showed a high negative correlation with this dimension (correlation $=-$ 0.98). Regarding watersheds, Tromen and Curruhue - Huechulafquen showed a negative and positive correlation with this dimension $\left(\cos ^{2}=0.93\right.$ and 0.7 respectively). Climate data and bioclimatic variables were not correlated with first nor second dimensions.

a

今.

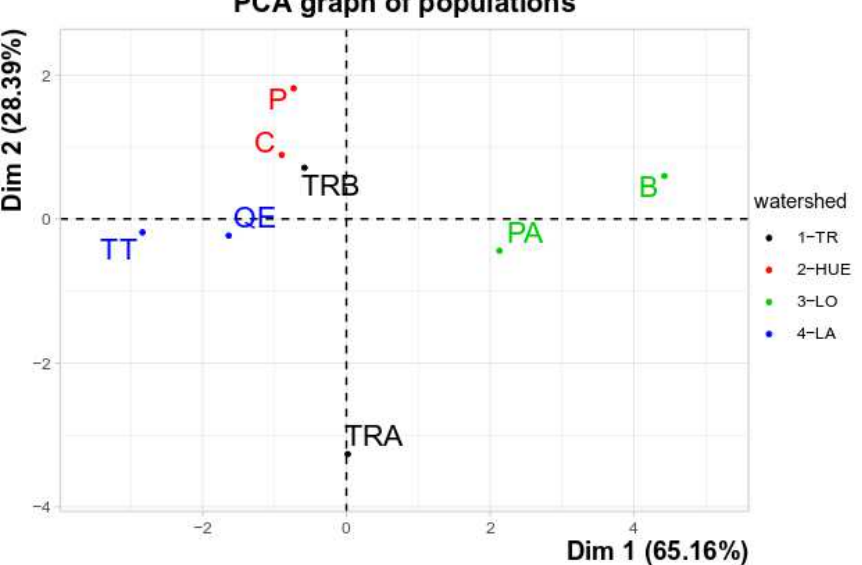

b

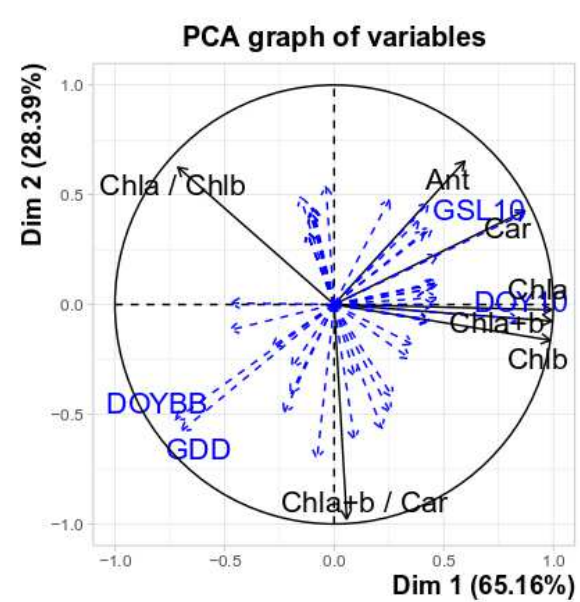

Fig. 6. First plane of Principal Component Analysis (PCA) of a) populations and b) active (black) and supplementary (blue) quantitative variables. Variable labels are only showed for variables with good representation in the plane (i.e. $\cos ^{2}$ greater than 0.6). 


\section{Discussion}

\subsection{Phenotypic plasticity of N. alpina pigment content}

The two analysed years varied particularly in the distribution of total precipitation and, consequently, aridity index over months. This inter-annual variation constitutes a good scenario to test temporal phenotypic plasticity. The significance of the environmental factor (year) in the linear mixed models tested is evidence of phenotypic plasticity of pigment content, since their concentration varied when the same genotypes were exposed to different environmental conditions. Additionally, the lack of significance of the interaction between year and population or watershed (environmental and genetic factors, respectively) should be interpreted as the lack of genetic control of the detected plasticity itself (Whitman and Agrawal 2009), which can be clearly visualized in the parallel dotted lines of Fig 3. and Fig. 4.

All pigment concentrations were significantly higher in 2018. However, inter-annual variation was higher for anthocyanins (i.e twice for 2018) than for the other pigments. Regarding pigment ratios, only Chla+b / Car was significantly higher in 2018 than in 2019, with populations Tromen Alto and Tren Tren showing the highest values. The year 2018 showed higher and lower values of aridity index than 2019 during summer/spring and autumn/winter, respectively. Moreover, 2018 showed less stressful conditions during the last and the first part of the growing seasons 2017-2018 and 2018-2019, respectively, than those of the historical periods. Conversely, 2019 showed more stressful conditions than those of the historical periods during growing seasons. Inter-annual leaf pigment variation has been also reported in other species under contrasting environmental conditions, although specific patterns depend on pigments, species and variation of environmental conditions between years (Mészáros et al. 2007; Uvalle Sauceda et al. 2007; Szollosi et al. 2011). For example, in a comparative study, over two growing seasons, Quercus petraea showed lower concentrations of total chlorophyll and carotenoids in the driest year; while Quercus cerris showed similar and lower content of total chlorophyll and carotenoids for the same year respectively (Mészáros et al. 2007). In other study, however, both species showed lower total chlorophyll and higher total carotenoids during the growing season with higher annual mean temperature and summer 
heat waves (Szollosi et al. 2011). In our study, aridity index during growing seasons was lower for 2019 than mean values of historical periods. Conversely, for 2018 values were higher and, particularly in the growing season were globally within the per-humid class. Although pigment content variation could be determined by stressful conditions of 2019 , the detected pattern suggests it is more probable related with the unusual benign environmental conditions of 2018. Our results in $N$. alpina also suggest high sensitivity of pigment content to the distribution of total precipitation over the year. However, we could not rule out that variation in other non-evaluated environmental conditions (e.g. wind speed, solar radiation) also influenced pigment content.

\subsection{Genetic variation of $N$. alpina pigment content}

Population and watershed were significant factors conditioning the concentration of chlorophyll $a$, chlorophyll $b$, total chlorophyll, carotenoids and anthocyanins, according to the linear mixed models tested. Moreover, the family factor was shown to have an influence on the variance of the pigment traits. These results are evidence of the genetic control as well as the potential adaptive value of leaf pigment content in $N$. alpina. Interspecific variation might explain more than $80 \%$ of the total variation of chlorophylls, with coefficient of variations around 0.4 for Chla, Chlb and Chla+b (Li et al. 2018 a). High interspecific variation has been also reported for carotenoids (e.g. Asner et al., 2009; Bündchen et al., 2016). In turn, intraspecific variation has been also reported for leaf pigments (e.g. Kaluthota et al., 2015; Martin et al., 2006; Ramírez-Valiente et al., 2015; Simões et al., 2020; Wang et al., 2020). In N. alpina, intraspecific variation for total chlorophyll has been previously reported based on nondestructive measurements by a portable chlorophyll meter (Duboscq-Carra 2018). As far as we know, reports on intraspecific variation of other pigments are not available for the species. In our study, for all pigments, higher values were detected in population Boquete, located at the western edge, near the Andes, while the lowest values correspond always to Tren Tren population, at an eastern site. However, as for inter-annual variation, differences were higher for anthocyanins. High pigment content is usually characteristic of shade tolerant leaves (García-Plazaola and Becerril 2000; Wang et al. 2020), which coincides with denser 
forests at western sites. This pattern could be also related with the west-east decrease on precipitation, as negative impact of drought in pigment concentrations has been previously reported (García-Plazaola and Becerril 2000; Esteban et al. 2015). However, the differentiation among watersheds indicates that, besides longitudinal location, other environmental factors would be conditioning pigment content. Lolog and Lácar were the most differentiated watersheds, with the highest and the lowest pigment content respectively. This pattern was also not related to the latitudinal location. Moreover, no correlation was detected between pigment content and i) altitude, mean annual precipitation or mean January and July temperatures of geographic locations (data from local databases), or ii) climatic or bioclimatic data (from WorldClim and Chelsa databases). Results of principal component analysis also agree with this trend, as pigment content separate populations, and this separation was better associated with watershed than with longitudinal location; and climatic and bioclimatic variables were not associated with population separation. Intraspecific differences in anthocyanins were also detected in Quercus spp. (Ramírez-Valiente et al. 2015), where an association between freezing tolerance and lower anthocyanin content was observed. In our case, although correlations between pigment traits and climatic variables at the home environments were not significant, the populations with the lowest anthocyanin content (Tren Tren and Tromen Alto) correspond to open forests towards eastern locations where the impact of frosts might be higher. This could suggest an adaptation to cold temperatures. watershed) were separated according to Chla / Chlb and Chla+b / Car. Genetic variation was globally not detected by linear mixed models (neither for population nor watershed). However, a tendency of higher values for Tromen Alto and Tren Tren and lower values for Tromen Bajo and Paimún was detected. This tendency partially agrees with results from multivariate analysis. 

factor considered (Esteban et al. 2015), with a small coefficient of variation among different species, life forms, and communities (Li et al., 2018a). However, Chla and Chlb differ in their absorption peaks and are mainly associated to different photosystems (Li et al. 2018b). Therefore, the lower value of Chla / Chlb associated with Boquete and Puerto Arturo (Lolog watershed) and Tromen Alto (Tromen watershed) could be related to a better light availability, and consequently lower allocation to photosystem II. Carotenoids participate in light harvesting but are also involved in photoprotection (Esteban et al. 2015). Therefore, Chl $a+b /$ Car depends mainly on light conditions (Demmig-Adams et al. 1996). In addition, high values of Chla+b / Car are associated with a better cold acclimation (Rapacz et al. 2007). Among $N$. alpina populations, results suggest that environmental conditions determine a prioritization of light capture and a higher tolerance to cold in Tromen Alto (high value) while excess energy dissipation could be important in Paimún (low value). Although mean temperatures are similar between these two populations, Tromen Alto is a more open forest located at a higher altitude, with a lowest mean annual precipitation than Paimún, and this micro-site conditions might promote more intense frosts.

High correlations between phenological and pigment traits indicate that, in $N$. alpina, the determination of only one pigment concentration could be used as a proxy of bud burst, senescence and growing degree days. Correlations were expected as genetic variation patterns (e.g. more differentiated populations) were similar for both types of traits, suggesting that similar environmental factors are influencing their variation. Phenological evaluations are very time-consuming, therefore using pigment quantification to estimate phenological traits could prompt progeny and provenance trial evaluations. Correlations between both traits and promising results on pigment based vegetation indices have been previously reported in other forest tree species (e.g. Anderson and Ryser, 2015; Wong et al., 2019; Yang et al., 2017). Globally, the phenotypic plasticity detected in the analysed populations of $N$. alpina suggest flexibility for acclimatization to moderate inter-annual changes in climatic conditions.

485 On the other hand, the genetic control of pigments content and its variation among 
populations and watersheds gives a base for adaptation to a long-lasting change in climate.

487 Future studies must focus on identifying the factors that determine the genetic variation.

488

Abbreviations: Chlorophyll a (Chla); Chlorophyll b (Chlb); Total chlorophyll (Chla+b);

490

Chlorophyll allocated ratio (Chla / Chlb); Total carotenoids (Car); Anthocyanins (Ant); Monthly

491

mean air temperature (Tmean); Monthly minimum air temperature (Tmin); Monthly maximum

492

air temperature (Tmax); Aridity index (Al); Total precipitation (precip); Rainy days (rd); Linear

493

mixed effects model (LMM); Likelihood ratio test (LRT); Principal component analysis (PCA)

494

495

Day of the year to bud burst (DOY BB); Growing degree days (basal temperature $=5{ }^{\circ} \mathrm{C}$ )

(GDD Tb $5^{\circ} \mathrm{C}$ ); Day of the year when $10 \%$ of the crown had autumnal leaves (DOY 10)

496

Growing season length (GSL 10)

497

498

499

5. Ethics approval and consent to participate

Not applicable

500

6. Consent for publication

501

Not applicable

502

\section{Availability of data and material}

503

The data will be available upon acceptance in the public institutional repository INTA Digital

504 (www.repositorio.inta.gob.ar)

\section{Competing interest}

\section{6}

507

The authors declare that they have no known competing financial interests or personal relationships that could have appeared to influence the work reported in this paper.

\section{Funding}

509

This work was supported by the project "Restauración ecosistémica y domesticación de especies forestales nativas patagónicas con gran potencialidad productiva: bases genéticas de la adaptación a estrés hídrico y térmico" PICT 20161116 ANPCyT. 
PM and VEM conceptualized the study. JAR, PM, VEM performed sample collections. JAR performed pigment quantification and statistical analyses and wrote the manuscript with the contributions of PM and VE. MP installed and maintained the common garden trial. All authors were involved in the final revision and editing process of the manuscript.

\section{Acknowledgements}

We would like to thank Fernando Barbero for his collaboration in seed collection and seedling production, Mario Huentú and Abel Martínez for their help in the installation of the trial, the staff of the Campo Forestal General San Martin for helping with trial maintenance. Authors would also thank Valeria Álvarez, Cecilia Roldán and Verónica Guidalevich for their collaboration on field work. Climate data were kindly provided by the Servicio Meteorológico Nacional of Argentina.

\section{References}

Aitken SN, Yeaman S, Holliday JA, et al (2008) Adaptation, migration or extirpation: climate change outcomes for tree populations. Evol Appl 1:95-111.

https://doi.org/10.1111/j.1752-4571.2007.00013.x

Alexander LV, Zhang X, Peterson TC, et al (2006) Global observed changes in daily climate extremes of temperature and precipitation. J Geophys Res Atmos 111:1-22. https://doi.org/10.1029/2005JD006290

Anderson R, Ryser P (2015) Early autumn senescence in red maple (Acer rubrum L.) is associated with high leaf anthocyanin content. Plants 4:505-522. https://doi.org/10.3390/plants4030505

Asner GP, Martin RE, Ford AJ, et al (2009) Leaf chemical and spectral diversity in Australian tropical forests. Ecol Appl 19:236-253. https://doi.org/10.1890/08-0023.1

Azpilicueta MM, Gallo LA, van Zonneveld M, et al (2013) Management of Nothofagus genetic resources: Definition of genetic zones based on a combination of nuclear and chloroplast 
Barros VR, Boninsegna JA, Camilloni IA, et al (2015) Climate change in Argentina: Trends, projections, impacts and adaptation. Wiley Interdiscip Rev Clim Chang 6:151-169. https://doi.org/10.1002/wcc.316

Bates D; Mächler M; Bolker B; Walker S (2016) Ime4: fitting linear mixed-effects models using Eigen and S4., $\mathrm{R}$ package version 1.1-8.

Bianchi A; Cravero C (2010) Atlas Climático Digital de la República Argentina- Instituto Nacional de Tecnología Agropecuaria. Ediciones INTA, Salta.

Bündchen M, Boeger MRT, Reissmann CB, Geronazzo KM (2016) Interspecific variation in leaf pigments and nutrients of five tree species from a subtropical forest in southern Brazil. An Acad Bras Cienc 88:467-477. https://doi.org/10.1590/0001-

Chalker-Scott L (1999) Environmental significance of anthocyanins in plant stress responses. Photochem Photobiol 70:1-9. https://doi.org/10.1111/j.1751-1097.1999.tb01944.x

De Martonne E (1926) Aerisme, et índices d'aridite. Comptesrendus L'Academie des Sci 182:1395-1398

De Villemereuil P, Mouterde M, Gaggiotti OE, Till-Bottraud I (2018) Patterns of phenotypic plasticity and local adaptation in the wide elevation range of the alpine plant Arabis

Demmig-Adams B, Gilmore AM, lii WA (1996) In vivo functions of carotenoids in higher plants. FASEB J 10:403-412. https://doi.org/10.1096/fasebj.10.4.8647339

Donoso C (2004) Variación intraespecífica en las especies arbóreas de los bosques templados de Chile y Argentina

Duboscq-Carra VG (2018) “Variación y diferenciación genética de Nothofagus alpina : proyecciones para su domesticación y análisis de sus estrategias evolutivas en el contexto del cambio climático global" Universidad Nacional del Comahue

Duboscq-Carra VG, Arias-Rios JA, El Mujtar VA, et al (2020) Differentiation in phenology among and within natural populations of a South American Nothofagus revealed by a 
two-year evaluation in a common garden trial. For Ecol Manage 460:117858. https://doi.org/10.1016/j.foreco.2019.117858

Esteban R, Barrutia O, Artetxe U, et al (2015) Internal and external factors affecting photosynthetic pigment composition in plants: A meta-analytical approach. New Phytol 206:268-280. https://doi.org/10.1111/nph.13186

Feild TS, Lee DW, Holbrook NM (2001) Why leaves turn red in autumn. The role of anthocyanins in senescing leaves of red-osier dogwood. Plant Physiol 127:566-574. https://doi.org/10.1104/pp.010063

Fick SE, Hijmans RJ (2017) WorldClim 2: new 1-km spatial resolution climate surfaces for global land areas. Int J Climatol 37:4302-4315. https://doi.org/10.1002/joc.5086

Fisichelli NA, Frelich LE, Reich PB (2014) Temperate tree expansion into adjacent boreal forest patches facilitated by warmer temperatures. Ecography (Cop) 37:152-161. https://doi.org/10.1111/j.1600-0587.2013.00197.x

García-Plazaola JI, Becerril JM (2000) Effects of drought on photoprotective mechanisms in European beech (Fagus sylvatica L.) seedlings from different provenances. Trees - Struct Funct 14:485-490. https://doi.org/10.1007/s004680000068

Gould KS, Markham KR, Smith RH, Goris JJ (2000) Functional role of anthocyanins in the leaves of Quintinia serrata A. Cunn. J Exp Bot 51:1107-1115.

Hawkins TS, Echt CS, Devall MS, et al (2019) Adaptive trait variation in the federally endangered Lindera melissifolia (Lauraceae), as it relates to genotype and genotypeenvironment interaction. J Torrey Bot Soc 146:166-173

IPCC (2014) Cambio climático 2014: Informe de Síntesis

Kaluthota S, Pearce DW, Evans LM, et al (2015) Higher photosynthetic capacity from higher latitude: Foliar characteristics and gas exchange of southern, central and northern populations of Populus angustifolia. Tree Physiol 35:936-948. https://doi.org/10.1093/treephys/tpv069

Karger DN, Conrad O, Böhner J, et al (2017) Climatologies at high resolution for the earth's 
Kawecki TJ, Ebert D (2004) Conceptual issues in local adaptation. Ecol Lett 7:1225-1241. https://doi.org/10.1111/j.1461-0248.2004.00684.x

Kremer A, Ronce O, Robledo-Arnuncio JJ, et al (2012) Long-distance gene flow and adaptation of forest trees to rapid climate change. Ecol Lett 15:378-392. https://doi.org/10.1111/j.1461-0248.2012.01746.x

Li Y, He N, Hou J, et al (2018a) Factors influencing leaf chlorophyll content in natural forests at the biome scale. Front Ecol Evol 6:1-10. https://doi.org/10.3389/fevo.2018.00064

Li Y, Liu C, Zhang J, et al (2018b) Variation in leaf chlorophyll concentration from tropical to cold-temperate forests: Association with gross primary productivity. Ecol Indic 85:383389. https://doi.org/10.1016/j.ecolind.2017.10.025

Lichtenthaler HK (1987) Chlorophylls and Carotenoids: Pigments of Photosynthetic Biomembranes. Methods Enzymol 148:350-382. https://doi.org/10.1016/0076$6879(87) 48036-1$

Lloyd AH, Bunn AG, Berner L (2011) A latitudinal gradient in tree growth response to climate warming in the Siberian taiga. Glob Chang Biol 17:1935-1945. https://doi.org/10.1111/j.1365-2486.2010.02360.x

Major J (1951) A Functional , Factorial Approach to Plant Ecology Author.Ecology 3:392-412 Marchelli P, Pastorino MJ, Azpilicueta MM, Duboscq Carra VG, Sola GG, El Mujtar VA, et al (2021b) Raulí (Nothofagus alpina = N. nervosa): The Best Quality Hardwood in

Marchelli P, Gallo LA (2006) Multiple ice-age refugia in a southern beech of South America as evidenced by chloroplast DNA markers. Conserv Genet 7:591-603. https://doi.org/10.1007/s10592-005-9069-6

Marchelli P, Pastorino MJ, Gallo LA (2021a) Temperate Subantartic Forests: a Huge Natural 
Trees in Argentina: Genetic Basis for their Domestication and Conservation, Springer. Cham, Switzerland, pp 27-54.

Martin RE, Asner GP, Sack L (2006) Genetic variation in leaf pigment, optical and photosynthetic function among diverse phenotypes of Metrosideros polymorpha grown in a common garden. Oecologia 151:387-400. https://doi.org/10.1007/s00442-006-0604-z

Mészáros I, Veres S, Kanalas P, et al (2007) Leaf Growth and Photosynthetic Performance of Two Co-existing Oak Species in Contrasting Growing Seasons. Acta Silv Ling Hung 3:720

Parmesan C, Hanley ME (2015) Plants and climate change: Complexities and surprises. Ann Bot 116:849-864. https://doi.org/10.1093/aob/mcv169

Ramírez-Valiente J, Koehler K, Cavender-Bares J (2015) Climatic origins predict variation in photoprotective leaf pigments in response to drought and low temperatures in live oaks (Quercus series Virentes). Tree Physiol 35:521-534. https://doi.org/10.1093/treephys/tpv032

Rapacz M, Gąsior D, Kościelniak J, et al (2007) The role of the photosynthetic apparatus in cold acclimation of Lolium multiflorum. Characteristics of novel genotypes low-sensitive to PSII over-reduction. Acta Physiol Plant 29:309-316. https://doi.org/10.1007/s11738-007-

\section{0-7}

RStudio Team (2020) RStudio: Integrated Development for R. RStudio

Sabatier Y, Azpilicueta MM, Marchelli P, et al (2011) Distribución natural de Nothofagus alpina y Nothofagus obliqua (Nothofagaceae) en argentina, dos especies de primera importancia forestal de los bosques templados norpatagónicos. Bol Soc Argentina Bot $46: 131-138$

Simões R, Rodrigues A, Ferreira-Dias S, et al (2020) Chemical composition of cuticular waxes and pigments and morphology of leaves of quercus suber trees of different provenance. Plants 9:1-15. https://doi.org/10.3390/plants9091165

Sims DA, Gamon JA (2002) Relationships between leaf pigment content and spectral reflectance across a wide range of species, leaf structures and developmental stages. 
Soliani C, Azpilicueta MM, Arana MV, Marchelli P (2020) Clinal variation along precipitation gradients in Patagonian temperate forests: unravelling demographic and selection signatures in three Nothofagus spp. Ann For Sci 77:. https://doi.org/10.1007/s13595-0190908-x

Szollosi E, Oláh V, Kanalas P, et al (2011) Physiological responses of two co-existing oak species in years with contrasting climatic conditions. Acta Biol Szeged 55:169-174

Taiz, L., \& Zeiger E (2002) (2002) Plant Physiology. Sinauer Assoc 18:677-694. https://doi.org/10.1111/j.1440-1703.2003.00588.x

Uvalle Sauceda JI, González Rodríguez H, Ramírez Lozano RG, et al (2007) Seasonal trends of chlorophylls $a$ and $b$ and carotonoids in native trees and shrubs of Northeastern Mexico. J Biol Sci 8:258-267. https://doi.org/10.3923/jbs.2008.258.267

Violle C, Navas M-L, Vile D, et al (2007) Let the concept of trait be functional! Oikos 116:882892. https://doi.org/10.1111/j.2007.0030-1299.15559.x

Wang F, Israel D, Ramírez-Valiente JA, et al (2020) Seedlings from marginal and core populations of European beech (Fagus sylvatica L.) respond differently to imposed drought and shade. Trees - Struct Funct 35:53-67. https://doi.org/10.1007/s00468-020$02011-9$

Whitman D, Agrawal A (2009) What is phenotypic plasticity and why is it important. In: Phenotypic plasticity of insects: Mechanisms and consequences. pp 1-63

Wong CYS, D'Odorico P, Bhathena Y, et al (2019) Carotenoid based vegetation indices for accurate monitoring of the phenology of photosynthesis at the leaf-scale in deciduous and evergreen trees. Remote Sens Environ 233:111407. https://doi.org/10.1016/j.rse.2019.111407

Yang H, Yang X, Heskel M, et al (2017) Seasonal variations of leaf and canopy properties tracked by ground-based NDVI imagery in a temperate forest. Sci Rep 7:1-10. https://doi.org/10.1038/s41598-017-01260-y 